\title{
Mazindol Treatment of Negative Symptoms
}

\author{
William T. Carpenter, Jr., M.D., Alan Breier, M.D., Robert W. Buchanan, M.D., \\ Brian Kirkpatrick, M.D., Paul Shepard, Ph.D., and Elaine Weiner, M.D.
}

\begin{abstract}
Hypodopaminergic and hyponoradrenergic pathophysiology may be a basis for primary and/or secondary negative symptoms in schizophrenia. The hypothesis that enhanced neurotransmission in these systems would be therapeutic for negative symptoms was tested by comparing mazindol and placebo in a double-blind, cross-over design trial.

Outcome following mazindol supplementation was comparable to placebo supplementation $(F(1,30)=0.9 ; \mathrm{p}=$ .57). Results for deficit and non-deficit schizophrenia
\end{abstract}

subjects were similar, and were not affected by whether concurrent the antipsychotic drug treatment was clozapine, fluphenazine, or haloperidol. The efficacy hypothesis was not supported for either primary or secondary negative symptoms. [Neuropsychopharmacology 23:365-374, 2000] (C) 2000 American College of Neuropsychopharmacology. Published by Elsevier Science Inc.
KEY WORDS: Schizophrenia; Mazindol; Negative symptoms; Clinical trial; Dopamine

Many mental and physical states can temporarily reduce an individual's ability to experience pleasure, gratification, and reinforcement. However, when Rado (1956) described anhedonia as a core feature of schizophrenia, he referred to an enduring or trait reduction in capacity rather than a transitory or state impairment. Meehl (1962) elaborated this concept in the context of a trait neurointegrative disability associated with schizophrenia. Stein and Wise (1971) subsequently introduced the hypothesis that neurotoxic damage to the noradrenergic reward system was present in schizophrenia. This latter theory, while not capable of accounting for the broad range of clinical manifestations of the disease, seemed a highly cogent hypothesis for anhedonia per se (Strauss and Carpenter 1972).

From the Maryland Psychiatric Research Center, Department of Psychiatry, University of Maryland, Baltimore, MD. A.B. current affiliation: Lilly Research Laboratories, Lilly Corporate Center, Indianapolis, IN.

Address correspondence to: William T. Carpenter, Jr., M.D., Maryland Psychiatric Research Center, P.O. Box 21247, Baltimore, MD 21228.

Received March 8, 2000; revised March 8, 2000; accepted March 14,2000
Negative symptoms of schizophrenia are defined more broadly than anhedonia, but the core features of reduced social drive, restricted emotional experience and expression, alogia, and a diminished capacity for the experience of pleasure are hypothesized to emerge from pathophysiology in the neural circuits concerned with drive, emotion, and reward. Dopaminergic and noradrenergic neurons are central to the mediation of these experiences (Schultz 1997).

These considerations suggest a therapeutic hypothesis, that enhanced neurotransmission in noradrenergic and/or dopaminergic systems would be therapeutic for negative symptoms. In particular, the dopaminergic mesocortical projections and noradrenergic circuitry involved with reward are seen as possible neural substrates for the negative symptoms of schizophrenia (Weinberger 1987; Davis et al. 1991). Developing a treatment based on either of these presumptions is not straightforward, however, since the hyperdopaminergic mesolimbic hypothesis would predict that a drug that reduces negative symptoms would have the potential liability of increasing positive symptoms.

An approach to enhancing mesocortical dopaminergic activity, while having little effect on other projections, is the use of dopamine reuptake inhibitors. This approach is based on the observation that dopamine 
turnover rates in the mesocortical projection are two to four fold higher than in the mesolimbic or nigrostriatal systems (Agnati et al. 1980; Bannon et al. 1981; Thierry et al. 1976). Accordingly, a reuptake blocker should result in a faster accumulation and higher concentration of synaptic dopamine in cortical regions than in other dopamine terminal fields. Direct support for this hypothesis is provided by preclinical studies in which drugs that block amine transporters increase dopamine levels in the prefrontal cortex but not in the nucleus accumbens (Carboni et al. 1990; Tanda et al. 1994). Blockade of the noradrenergic transporter contributes directly to the selective increase in mesocortical dopamine levels, presumably by preventing heterologous uptake into norepinephrine-containing nerve terminals in the cortex (Tanda et al. 1997).

The rationale for this strategy has received support from previous clinical trials. Previous studies have suggested that drugs which enhance the release of DA and other monoamines may be effective in reducing negative symptoms (Angrist et al. 1980, 1982; Cesarec and Nyman 1985; Van Kammen and Boronow 1988; Mathew and Wilson 1989; Goldberg et al. 1991; Sanfilipo et al. 1996). The negative symptom advantage sometimes reported with antipsychotic drugs that have robust serotonin antagonism may be an indirect effect of diminishing inhibition of dopamine neurons (Schmidt and Fadayel 1995; Kapur and Remington 1996). A similar advantage has been associated with selective serotonin reuptake inhibitors (Silver and Nassar 1992; Spina et al. 1994; Goff et al. 1995a; see also Buchanan et al. 1996). These seemingly paradoxical findings could be resolved if one considers that SSRIs administered in the presence of antipsychotic drugs with affinity for 5-HT2 receptors could indirectly increase DA levels in the prefrontal cortex via activation of inhibitory serotonergic autoreceptors. Alternatively, it has been suggested that the ability of both SSRIs and 5-HT antagonists to improve negative symptoms could reflect a differential effect of these drugs on the depressive (SSRI-sensitive) and extrapyramidal (5-HT2 antagonists-sensitive) components of these symptoms (Kapur and Remington 1996). Finally, it should also be noted that noradrenergic reuptake inhibitors have also been used to successfully to treat negative symptoms (Yamagami and Soejima 1989; Siris et al. 1987) and that clozapine, sometimes observed to be superior in the treatment of negative symptoms (Lieberman et al. 1994) is associated with a substantial increase in norepinephrine concentrations (Breier et al. 1994).

However, in all of these studies, there is usually no effort made to take into account the effect of the putative therapeutic agents on sources of secondary negative symptoms. The failure to control for potential effects on secondary negative symptoms leaves unanswered the question of whether these agents are having a direct effect on negative symptoms, or are exerting their therapeutic effect through their anti-parkinsonian and/or antidepressant properties. In the present study we examine whether mazindol is effective for either primary and/or secondary negative symptoms when added to a conventional antipsychotic, or when added to clozapine. Mazindol is a potent antagonist of both DA and NE transporters (Heikkila et al. 1977) and is selected for testing on the basis of preliminary reports of its efficacy in the treatment of negative symptoms (Seibyl et al. 1991).

\section{METHODS}

\section{Subjects}

Thirty-nine patients meeting DSM-III-R criteria for schizophrenia or schizoaffective disorder were selected from the Maryland Psychiatric Research Center Outpatient Research Program for entry into the study. Patients were diagnosed using a best estimate diagnostic approach that utilized all available information from a structured diagnostic interview (Structured Clinical Interview for DSM-III-R), direct assessment, family informants, and past medical records. Patients with concurrent drug abuse or alcoholism, organic brain disorders, mental retardation, or a medical condition that contraindicated any study medication were excluded from the study. All patients provided written informed consent prior to participating in the study.

Patients were relatively chronic and stable outpatients and were required to exhibit a minimum level of negative symptoms. The minimum negative symptom level was a total score of at least 20 on the Scale for the Assessment of Negative Symptoms, or SANS (Andreasen 1984), or a score of at least 2 on at least one SANS global item.

\section{Study Design}

Patients were randomly assigned to placebo or mazindol in an all-blind, balanced-order, cross-over design, with a four-week washout at cross-over and admission to the second condition only if baseline criteria were met again. Each treatment phase was eight weeks. Patients randomized to mazindol received three 1-mg tablets in the morning. If a patient could not tolerate this dose, then downward dose adjustments were permitted. Patients randomized to placebo also received three tablets in the morning. Patients were continued on their current dose of oral fluphenazine, haloperidol, or clozapine throughout the study. The mean daily dose (oral) is given in Table 1. Compliance was assessed by a weekly pill count and weekly medication review. In addition, all patients had a compliance plan that consisted of medication checks by family and/or mental health 
Table 1. Demographic and Clinical Characteristics of the Sample: Mean (SD)

\begin{tabular}{lc}
\hline & $N=\mathbf{3 9}$ (20 Deficit, 19 Non-deficit) \\
\hline Age (yr) & $40(7)$ \\
Duration of Illness (yr) & $18(8)$ \\
Gender & $25 \%$ females; 75\% males \\
Race & $40 \%$ African Americans; 60\% Caucasian \\
Baseline positive symptoms & $2.26(1.02)$ \\
Baseline negative symptoms & $31.6(11.3)$ \\
Haloperidol/fluphenazine (mg) & $19.1(8.6)$ \\
Clozapine (mg) & $496(110)$ \\
\hline
\end{tabular}

care providers who had extensive contact with the patients. All patients who were judged to have received $75 \%$ or more of their assigned study medication were considered compliant.

\section{Clinical Assessments}

The patients were categorized into deficit and nondeficit subgroups using the Schedule for the Deficit Syndrome (SDS), a semi-structured interview of documented reliability in this population (kappa $=0.73$ for the global categorization) (Kirkpatrick et al. 1989). The SDS provides specific criteria for assessing the presence of negative symptoms, the duration of symptoms, and whether the symptoms are primary or secondary. Additional information is obtained from clinicians with long-standing contact with the patients and from family members. Positive symptoms were assessed by the average of the four Brief Psychiatric Rating Scale (BPRS) (Overall and Gorham 1962) positive symptom items (item scores range from 1 to 7): conceptual disorganization, hallucinations, unusual thought content, and suspiciousness. Since the SDS is not designed to measure change in negative symptoms, the SANS (item scores range from 0 to 5), which assesses both primary and secondary negative symptoms, was used to assess change in negative symptoms.

The Simpson-Angus Extrapyramidal Symptom Rating Scale (EPRS) (Simpson and Angus 1970), and the Maryland Psychiatric Research Center Tardive Dyskinesia Scale (MPRC-TD) (Cassady et al. 1997) were used to assess extrapyramidal symptoms and dyskinetic movements, respectively. The BPRS, SANS, EPRS, and MPRC-TD scales were administered weekly during each treatment phase; the BPRS and SANS were administered by the patients' therapists and the EPRS and MPRC-TD by research nurses. In addition to examining the direct effect of mazindol on positive and extrapyramidal symptoms, the BPRS and EPRS ratings provide a mechanism for ascertaining whether any observed change in secondary negative symptoms is due to change in either of these types of symptoms. Interrater intraclass correlation coefficients for these four instru- ments ranged from 0.76 to 0.90 . These measures of interrater reliability came from regularly scheduled reliability exercises that continued throughout the study. In these exercises, patient interviews were seen by all the raters, and ratings were made independently, then discussed.

Side effects and vital signs were obtained weekly; side effects were rated as either absent or present. These ratings were conducted by a nonblind research nurse. Weekly white blood counts were reviewed by the nonblind research nurse. All personnel except a research nurse were blind to treatment assignment and deficit/ nondeficit categorization.

\section{Statistical Analyses}

Comparative efficacy of mazindol versus placebo was examined in completer analyses. All patients completed the study. The two primary outcome measures were positive and negative symptom response, as measured by the BPRS positive symptom items and SANS total score, respectively. SANS total score included all items, except for the inappropriate affect, attentional, and global items. The inappropriate affect and attentional items were excluded because of recent factor analytic study results suggesting that these items are not closely related to negative symptoms (Buchanan and Carpenter 1994; Andreasen et al. 1995). The global items were excluded because they are redundant with the individual items.

Analyses of covariance (ANCOVAs) were used to compare treatment outcomes. Treatment condition (placebo, mazindol) was a within-subjects factor, while treatment order (placebo first vs. mazindol first), concurrent antipsychotic treatment (fluphenazine or haloperidol vs. clozapine), and deficit categorization (deficit vs. nondeficit) were between-subjects factors. Baseline symptom measures served as covariates. The use of deficit/nondeficit categorization as a grouping variable made possible an examination of primary versus secondary negative symptom response, thereby permitting us to determine whether deficit and nondeficit patients shared the same positive symptom response. 
Examining the effects of concurrent antipsychotic provided a comparison of the efficacy of mazindol in combination with conventional antipsychotics.

The same ANCOVA analytic procedure was used to examine the effect of mazindol for EPRS total and MPRC-TD dyskinesia scores. Demographic and clinical characteristics at baseline were compared between concurrent antipsychotic treatment groups (conventional vs. clozapine) using either analysis of variance or chisquare statistics. All probability values were two-tailed. In an exploratory framework, the effects of mazindol were examined for BPRS total and factor scores and SANS factor scores.

Effects of potential outliers were evaluated in a twostage process. First, the presence of outliers was detected in separate multiple regression models for each outcome measure. In the event an outlier was detected, the analysis of covariance was recalculated after removing the outliers.

The study had $95 \%$ power to detect a $20 \%$ change in baseline positive and negative symptoms, with a medium effect size (0.6), 39 subjects, and alpha set to 0.05 .

\section{RESULTS}

Thirty-nine subjects entered and completed the study. The patients were approximately $40 \pm 7$ years of age and had been ill for a mean of $18 \pm 8$ years. Approximately $25 \%$ of the sample consisted of females. Forty percent of the sample were African Americans, and $60 \%$ were Caucasians. Twenty patients were taking clozapine and 19 patients were taking typical neuroleptics during the study period. Subjects received a mean dose of $2.9 \pm 0.4 \mathrm{mg}$ mazindol per day over the course of the study. Four mazindol and three placebo patients required dose reductions. Six patients were prescribed diphenhydramine, and three were prescribed benztropine for extrapyramidal drug side effects. The demographics and clinical measures at baseline did not differ as a function of antipsychotic type or deficit class. Demographic and baseline clinical characteristics for the sample are shown in Table 1.

The negative symptom outcome following mazindol supplementation was comparable to placebo supplementation $(\mathrm{F}(1,30)=0.9 ; p=.33)$ for both deficit and nondeficit patients (deficit categorization by drug interaction $\mathrm{F}(1,30)=0.3 ; p=.57$ ) (Figure 1 ). The type of antipsychotic medication by experimental drug/placebo interaction was not significant $(\mathrm{F}(1,30)=3.74 ; p=.06)$, nor was the effect of order of drug versus placebo supplementation $(\mathrm{F}(1,30)=2.29 ; p=.14)$. SANS total score means (as modified, described above) are presented in Table 2. The trend of $p=.06$ was mainly the result of negative symptom improvement during placebo on conventional antipsychotics only when placebo followed mazindol. Contrariwise, on clozapine negative symptom improvement of mazindol was only observed if placebo treatment preceded mazindol. This seems unlikely to be a pharmacologically meaningful trend. Removing one outlier from the analysis did not yield significant treatment effects. There was no mazindol effect on any SANS subscale score (data not shown).

Mazindol did not differ from placebo relative to positive symptom response $(\mathrm{F}(1,30)=0.13 ; p=.72)$; deficit versus nondeficit status made no difference in this regard (deficit categorization by drug interaction $(\mathrm{F}(1,30)=0.01 ; p=.92)$ (Figure 2$)$. The positive symp-

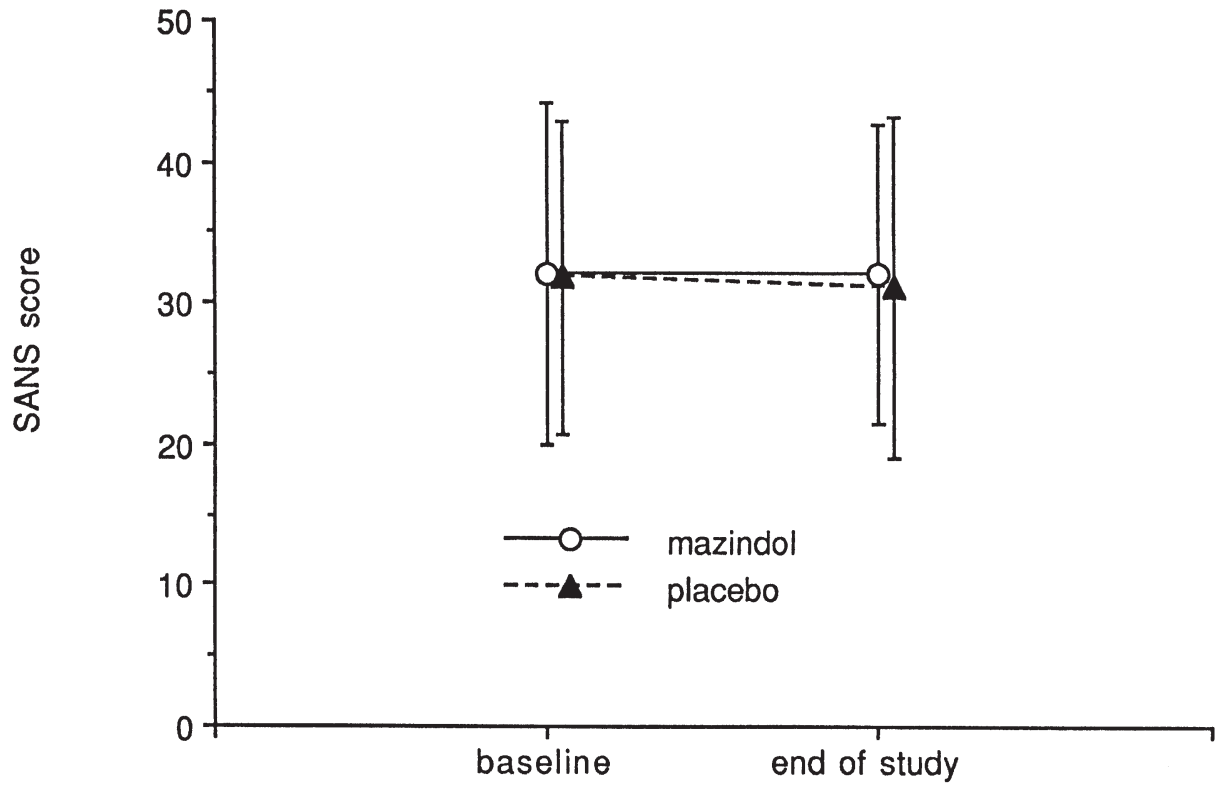

Figure 1. Negative symptom response to mazindol and placebo. The measure of negative symptoms was the total score on the Scale for the Assessment of Negative Symptoms, minus inappropriate affect, attentional, and global items. See Table 2 for details of the statistical analysis. 
Table 2. Sans - Total Score Means

\begin{tabular}{|c|c|c|c|c|c|c|c|c|c|}
\hline & \multirow[b]{3}{*}{$\mathbf{n}$} & \multicolumn{4}{|c|}{ Mazindol } & \multicolumn{4}{|c|}{ Placebo } \\
\hline & & \multicolumn{2}{|c|}{ Baseline } & \multicolumn{2}{|c|}{ End } & \multicolumn{2}{|c|}{ Baseline } & \multicolumn{2}{|c|}{ End } \\
\hline & & Mean & SD & Mean & SD & Mean & SD & Mean & SD \\
\hline \multicolumn{10}{|l|}{ DEFICIT } \\
\hline Haloperidol/fluphenazine & 11 & 38.27 & 13.56 & 40.36 & 13.24 & 39.45 & 12.96 & 36.00 & 9.76 \\
\hline Clozapine & 9 & 38.78 & 8.88 & 36.33 & 7.26 & 37.00 & 7.07 & 38.33 & 8.17 \\
\hline \multicolumn{10}{|l|}{ NONDEFICIT } \\
\hline Haloperidol/fluphenazine & 8 & 24.62 & 10.13 & 26.87 & 10.41 & 23.75 & 8.76 & 25.00 & 10.61 \\
\hline Clozapine & 11 & 25.82 & 8.78 & 24.18 & 8.83 & 26.09 & 5.70 & 24.91 & 7.35 \\
\hline
\end{tabular}

tom response did not differ when either conventional antipsychotic or clozapine treatment was supplemented by mazindol or placebo antipsychotic by drug interaction $(\mathrm{F}(1,30)=0.13 ; p=.72)$. The effect of order of drug or placebo supplementation was not significant $(\mathrm{F}(1,30)=0.05 ; p=.82)$. No outliers were detected in this analysis. BPRS positive symptom means are presented in Table 3.

EPRS ratings (Table 4) did not differ between mazindol and placebo treatment conditions $(\mathrm{F}(1,30)=0.97$; $p=.33$ ). Deficit and nondeficit patients had similar EPRS outcomes with mazindol and placebo supplementation (deficit categorization by drug interaction $\mathrm{F}(1,30)<0.001 ; p=.97)$. EPRS responses did not differ as a function of order of mazindol or placebo administration (antipsychotic by drug interaction $\mathrm{F}(1,30)=$ $0.02 ; p=.90)$. No outliers were detected in this analysis. EPRS total score means are presented in Figure 3.

Dyskinesia outcome did not differ between mazindol and placebo treatment $(\mathrm{F}(1,30)=1.35 ; p=.26)$. Dyskinesia outcomes did not differ as a function of deficit categorization (deficit categorization by drug interaction $\mathrm{F}(1,30)=1.35 ; p=.26$, order of treatment $(\mathrm{F}(1,30)=2.98 ; p=.09)$, or antipsychotic received during supplementation $(\mathrm{F}(1,30)=0.06 ; p=.82)$. Overall, dyskinesia scores reflected a mild severity level which was stable over the course of the study (mean (sd) at baseline $=3.08(3.17)$; endpoint $=3.03(3.15)$ ). No outliers were detected in this analysis.

Subjects receiving mazindol lost an average of 0.97 pounds, and subjects receiving placebo gained an average of 0.18 pounds (these differences were not significant). There was no significant interaction with clozapine versus traditional neuroleptics.

\section{DISCUSSION}

In this study, the efficacy of mazindol did not differ significantly from that of placebo when used as an adjunct to antipsychotic treatment in stable outpatients with schizophrenia. The proportion of patients with $20 \%$ im-

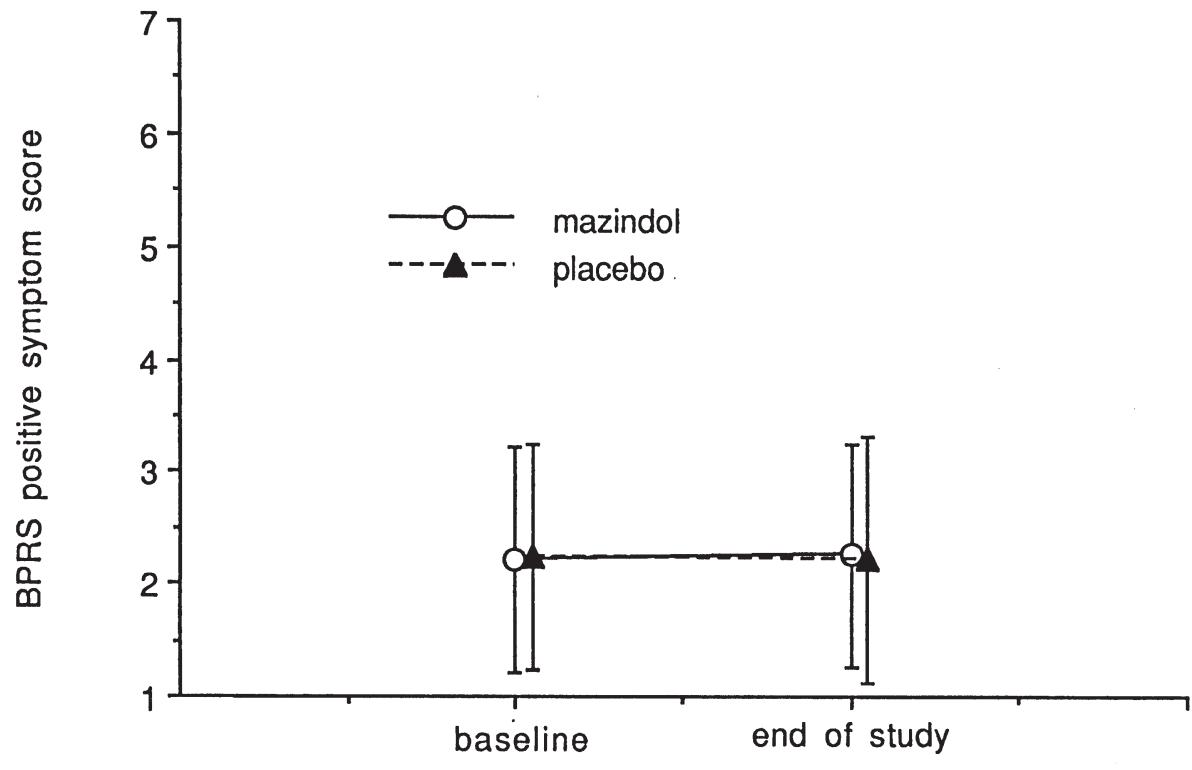

Figure 2. Positive symptom re sponse to mazindol and placebo. The measure of positive symptoms was the sum of the four BPRS positive symptom items. See Table 3 for details of the statistical analysis. 
Table 3. BPRS - Positive Symptoms Means

\begin{tabular}{|c|c|c|c|c|c|c|c|c|c|}
\hline & \multirow[b]{3}{*}{$\mathbf{n}$} & \multicolumn{4}{|c|}{ Mazindol } & \multicolumn{4}{|c|}{ Placebo } \\
\hline & & \multicolumn{2}{|c|}{ Baseline } & \multicolumn{2}{|c|}{ End } & \multicolumn{2}{|c|}{ Baseline } & \multicolumn{2}{|c|}{ End } \\
\hline & & Mean & SD & Mean & SD & Mean & SD & Mean & SD \\
\hline \multicolumn{10}{|l|}{ DEFICIT } \\
\hline Haloperidol/fluphenazine & 11 & 1.83 & 0.76 & 1.70 & 0.94 & 1.88 & 0.79 & 1.65 & 0.60 \\
\hline Clozapine & 9 & 1.91 & 0.79 & 2.18 & 0.83 & 2.07 & 0.88 & 2.27 & 1.06 \\
\hline \multicolumn{10}{|l|}{ NONDEFICIT } \\
\hline Haloperidol/fluphenazine & 8 & 2.30 & 0.84 & 2.17 & 0.60 & 2.08 & 1.06 & 2.28 & 1.03 \\
\hline Clozapine & 11 & 2.76 & 1.32 & 2.90 & 1.06 & 2.81 & 1.18 & 2.71 & 1.12 \\
\hline
\end{tabular}

provement on SANS total was 10 and 13 for placebo and mazindol, respectively. Examination of SANS subscales also suggested no difference. Twenty percent improvement rates on BPRS total were $13 \%$ and $8 \%$, respectively, and EPS were $31 \%$ and $21 \%$, respectively. There was no change in the pattern of response when mazindol was added to clozapine instead of a conventional antipsychotic, nor was there a difference between patients with primary negative symptoms and those manifesting only secondary negative symptoms. It is also noteworthy that mazindol did not exacerbate positive symptoms in this trial. The lack of treatment effects could not be attributed to the presence of outliers.

The results of the present study are in contrast to those of previous studies examining the efficacy of dopaminergic and noradrenergic agents (Buchanan et al. 1996). There are several possible reasons for these differences. First, the current study was double-blind, placebo-controlled. In contrast, in the previous trial of a noradrenergic reuptake inhibitor, maprotiline (Yamagami and Soejima 1989), and in the previous study of mazindol, efficacy was only observed under openlabeled conditions. Second, study patients were stable outpatients, with low levels of positive, depressive, and extrapyramidal symptoms, which minimized our ability to detect any benefit for secondary negative symptoms. Previous studies of dopaminergic and noradrenergic agents have only shown a negative symptom response in the presence of a reduction of symptoms that cause secondary negative symptoms (Buchanan et al. 1996). Finally, we specifically selected patients with persistent negative symptoms for inclusion in the study.

Previous studies have found clinical and neurobiological differences between schizophrenia patients with versus those without primary negative symptoms (Buchanan et al. 1990, 1993, 1994, 1997; Fenton and McGlashan 1994; Fenton et al. 1994; Kirkpatrick et al. 1998; Tamminga et al. 1992). Previous studies have also suggested there may be differences in the treatment response of deficit and nondeficit patients (Carpenter et al. 1995; Kopelowicz et al. 1997). However, there was no

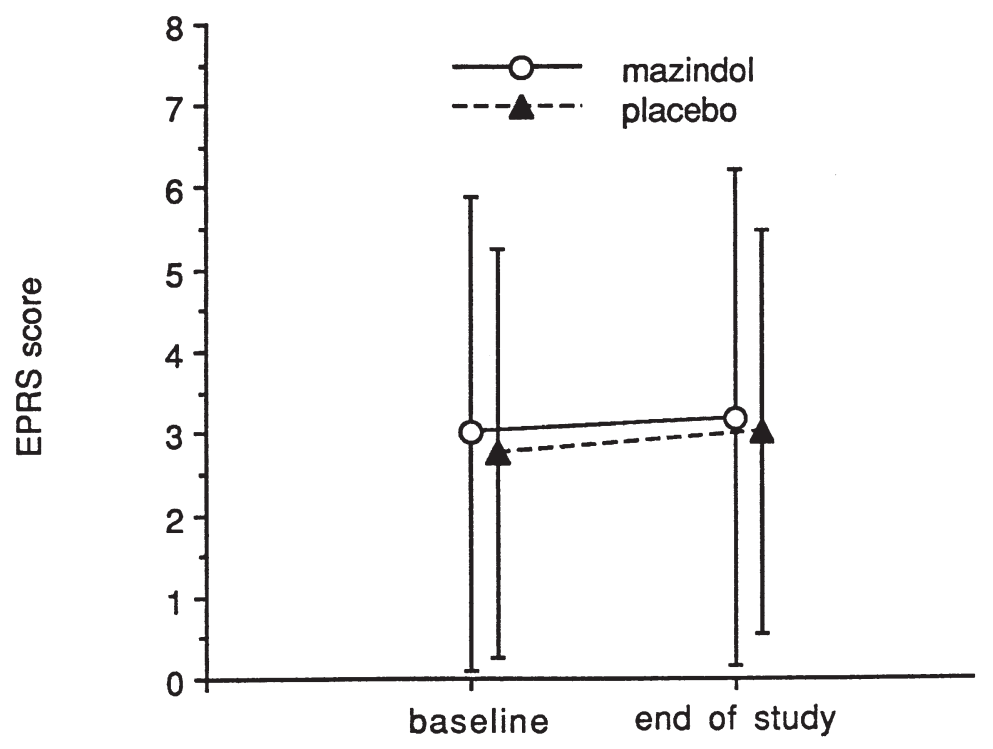

Figure 3. Motor side effects of mazindol and placebo, as measured by the Extrapyramidal Symptom Rating Scale. See Table 4 for details. 
Table 4. EPRS - Total Score Means

\begin{tabular}{|c|c|c|c|c|c|c|c|c|c|}
\hline & \multirow[b]{3}{*}{$\mathbf{n}$} & \multicolumn{4}{|c|}{ Mazindol } & \multicolumn{4}{|c|}{ Placebo } \\
\hline & & \multicolumn{2}{|c|}{ Baseline } & \multicolumn{2}{|c|}{ End } & \multicolumn{2}{|c|}{ Baseline } & \multicolumn{2}{|c|}{ End } \\
\hline & & Mean & SD & Mean & SD & Mean & SD & Mean & SD \\
\hline \multicolumn{10}{|c|}{ DEFICIT } \\
\hline \multicolumn{10}{|c|}{ Haloperidol/fluphenazine } \\
\hline Maz $1^{\text {st }}$ & 5 & 2.60 & 1.14 & 2.40 & 1.52 & 1.80 & 1.48 & 3.20 & 2.39 \\
\hline Plac $1^{\text {st }}$ & 6 & 4.67 & 5.01 & 5.17 & 5.56 & 3.17 & 3.66 & 3.83 & 3.19 \\
\hline \multicolumn{10}{|l|}{ Clozapine } \\
\hline Maz $1^{\text {st }}$ & 6 & 2.33 & 1.86 & 2.67 & 3.20 & 3.00 & 2.45 & 3.67 & 3.61 \\
\hline Plac $1^{\text {st }}$ & 3 & 3.00 & 1.73 & 4.67 & 1.15 & 3.67 & 2.52 & 2.67 & 1.53 \\
\hline \multicolumn{10}{|c|}{ NONDEFICIT } \\
\hline \multicolumn{10}{|c|}{ Haloperidol/fluphenazine } \\
\hline Maz $1^{\text {st }}$ & 4 & 5.00 & 2.70 & 4.25 & 1.25 & 4.75 & 2.22 & 3.25 & 0.96 \\
\hline Plac $1^{\text {st }}$ & 4 & 2.50 & 3.32 & 2.75 & 2.87 & 2.75 & 2.98 & 2.50 & 3.31 \\
\hline \multicolumn{10}{|l|}{ Clozapine } \\
\hline Maz $1^{\text {st }}$ & 4 & 1.75 & 1.26 & 2.75 & 2.98 & 1.75 & 1.26 & 1.75 & 1.25 \\
\hline Plac $1^{\text {st }}$ & 7 & 2.57 & 3.41 & 1.71 & 1.61 & 1.85 & 2.34 & 2.57 & 2.30 \\
\hline
\end{tabular}

suggestion that one of these groups was more responsive to mazindol than the other.

There are two major limitations associated with the study design. The first is that mazindol could be an effective treatment, but dosing parameters are not known, and the medication trial may have been inadequate in either dose or time. However, the dose used in this study is the same dose that was used in the openlabeled portion of the Yale study (Seibyl et al. 1992). In that study, $3 \mathrm{mg} /$ day of mazindol was found to be an effective dose. However, the lack of a functional, quantitative measure of dopaminergic or noradrenergic metabolism precludes a definitive statement on the appropriateness of that dose. With respect to the adequacy of study duration, the lack of any known effective treatment for primary negative symptoms precludes any judgment as to how long a trial should be in order to observe change in these symptoms. However, there have been several studies that have examined the effect of antipsychotics or adjunctive agents for persistent negative symptoms. In these studies, when an effect has been observed, it has always been observed within the time frame of the current study (Paillère-Martinot et al. 1995; Heresco-Levy et al. 1996; Goff et al. 1995b; Marder and Meibach 1994; Tollefson et al. 1997; Small et al. 1997).

A more serious limitation is the possibility that continuation of the antipsychotic drug treatment undermined the effectiveness of mazindol. Thus, although it was predicted that mazindol would produce a sufficient increase in dopamine concentration in the mesocortical dopamine projections to overcome the presence of antipsychotic drugs, it is possible that any increase in DA levels produced by mazindol was not sufficient to overcome the antipsychotic blockade of DA receptors.
However, avoiding high doses of haloperidol and fluphenazine, and the lack of efficacy of mazindol in reducing negative symptoms in patients treated with clozapine, a drug with only moderate affinity for dopamine receptors, suggests that ongoing antipsychotic treatment did not prevent mazindol efficacy. Feasibility for counteracting the antipsychotic blockade of DA receptors can also be inferred from methylphenidate challenge effects observed in patients on and off antipsychotic medication (Lieberman et al. 1984; Lieberman et al. 1987).

Despite the failure of the present study to demonstrate efficacy for mazindol in the treatment of negative symptoms, the theoretical construct upon which the trial was based is deserving of further study. Indeed, our results do not preclude the possibility that higher doses of the drug would have had a beneficial effect. Unfortunately, the lack of a quantitative measure of dopaminergic or noradrenergic metabolism (in our patients) makes it impossible to know whether the dose of mazindol used in the present study was appropriate. While comparable to that used in earlier open-labeled trials (Seibyl et al. 1991), the dose of mazindol used in the present study ( $3 \mathrm{mg} /$ day), is considerably lower than that typically used in preclinical studies (10-25 $\mathrm{mg} / \mathrm{kg}$ ) (Ng et al. 1992). Failure to achieve a significant enhancement in extracellular DA levels could explain the discrepancy between our results and previous studies demonstrating a reduction in negative symptoms following d-amphetamine.

Although mazindol binds with high affinity to the DA transporter $\left(\mathrm{IC}_{50}=80 \mathrm{nM}\right)$, its efficacy in increasing DA levels is less than other DA reuptake blockers including GBR 12909 and nomifensine and, unlike amphetamine, mazindol has only weak effects on DA release (Nakachi et al. 1995; Heikkila et al. 1977). In 
addition, mazindol has been reported to paradoxically increase $V_{\max }$ of the DA transporter, which could contribute to its comparatively modest effects in increasing basal DA levels (Ng et al. 1992). Thus, it seems reasonable to assume, even in the absence of an explicit measure of drug-induced changes in neurotransmitter levels, that the increase in DA levels produced by mazindol in the present study would be less than that achieved in patients receiving amphetamine. In conclusion, mazindol, given under the circumstances described in this study, is not superior to placebo in the treatment of negative symptoms. Although the hypodopaminergic/noradrenergic hypotheses for negative symptoms are not supported by these data, additional studies are needed to explore the potential therapeutic benefits derived from pharmacological interventions explicitly designed to increase DA levels in the frontal cortex of patients with deficit symptoms.

\section{ACKNOWLEDGMENTS}

This work was supported in part by PHS grants MH40279 and MH35996.

\section{REFERENCES}

Agnati LF, Fuxe K, Andersson K, Benfenati F, Cortelli P, D'Alessandro R (1980): The mesolimbic dopamine system: Evidence for high amine turnover and for a heterogeneity of the dopamine neuron population. Neurosci Lett 18:45-51

Andreasen NC (1984): The Scale for the Assessment of Negative Symptoms (SANS). Iowa City, Iowa, The University of Iowa

Andreasen NC, Arndt S, Alliger R, Miller D, Flaum M (1995): Symptoms of schizophrenia. Methods, meanings, and mechanisms. Arch Gen Psychiatry 52:341-351

Angrist B, Rotrosen J, Gershon S (1980): Differential effects of amphetamine and neuroleptics on negative vs. positive symptoms in schizophrenia. Psychopharmacology 72:17-19

Angrist B, Peselow E, Rubinstein M, Corwin J, Rotrosen J (1982): Partial improvement in negative schizophrenic symptoms after amphetamine. Psychopharmacology 78:128-130

Bannon MJ, Michaud RL, Roth RH (1981): Mesocortical dopamine neurons. Lack of autoreceptors modulating dopamine synthesis. Mol Pharmacol 19:270-275

Breier A, Buchanan RW, Waltrip RW, Listwak S, Holmes C, Goldstein DS (1994). The effect of clozapine on plasma norepinephrine: Relationship to clinical efficacy. Neuropsychopharmacology 10:1-7

Buchanan RW, Brandes M, Breier A (1996): Treating negative symptoms: Pharmacological strategies. In Breier A (ed), The New Pharmacotherapy of Schizophrenia. Washington, DC, American Psychiatric Press, pp 179-204
Buchanan RW, Breier A, Kirkpatrick B, Elkashef A, Munson RC, Gellad F, Carpenter WT (1993): Structural abnormalities in deficit vs. non-deficit schizophrenia. Am J Psychiatry 150:59-65

Buchanan RW, Carpenter WT (1994): Domains of psychopathology: An approach for the reduction of heterogeneity in schizophrenia. J Nerv Ment Dis 182:193-204

Buchanan RW, Kirkpatrick B, Heinrichs DW, Carpenter WT Jr (1990): Clinical correlates of the deficit syndrome of schizophrenia. Am J Psychiatry 147:290-294

Buchanan RW, Strauss ME, Breier A, Kirkpatrick B, Carpenter WT Jr (1997): Attentional impairments in deficit and nondeficit forms of schizophrenia. Am J Psychiatry 154(3):363-370

Buchanan RW, Strauss ME, Kirkpatrick B, Holstein C, Breier A, Carpenter WT Jr (1994): Neuropsychological impairments in deficit vs. nondeficit forms of schizophrenia. Arch Gen Psychiatry 51:804-811

Carboni E, Tanda G, Frau R, Di Chiara G (1990): Blockade of the noradrenaline carrier increases extracellular dopamine concentrations in the prefrontal cortex: Evidence that dopamine is taken up in vivo by noradrenergic terminals. J Neurochem 55:1067-1070

Carpenter WT Jr, Conley RR, Buchanan RW, Breier A, Tamminga CA (1995): Patient response and resource management: Another view of clozapine treatment of schizophrenia. Am J Psychiatry 152:827-832

Cassady SL, Thaker GK, Summerfelt A, Tamminga CA (1997): The Maryland Psychiatric Research Center Scale and the characteristics of involuntary movements. Psychiatry Res 70:21-37

Cesarec Z, Nyman AK (1985): Differential response to amphetamine in schizophrenia. Acta Psychiatr Scand 71:523-538

Davis KL, Kahn RS, Ko G, Davidson M (1991): Dopamine in schizophrenia: A review and reconceptualization. Am J Psychiatry 148:1474-1481

Fenton WS, McGlashan TH (1994): Antecedents, symptoms progression, and long-term outcome of the deficit syndrome in schizophrenia. Am J Psychiatry 151:351-356

Fenton WS, Wyatt RJ, McGlashan TH (1994): Risk factors for spontaneous dyskinesia in schizophrenia. Arch Gen Psychiatry 51:643-650

Goff DC, Midha KK, Sarid-Segal O, Hubbard JW, Amico E (1995a): A placebo-controlled trial of fluoxetine added to neuroleptic in patients with schizophrenia. Psychopharmacology 117:417-423

Goff DC, Tsai G, Manoach DS, Coyle JT (1995b): Dose-finding trial of d-cycloserine added to neuroleptics for negative symptoms in schizophrenia. Am J Psychiatry 152:1213-1215

Goldberg TE, Bigelow LB, Weinberger DR, Daniel DG, Kleinman JE (1991): Cognitive and behavioral effects of coadministration of dextroamphetamine and haloperidol in schizophrenia. Am J Psychiatry 148:78-84

Heikkila RE, Cabbat FS, Mytilineou C (1977): Studies on the capacity of mazindol and dita to act as uptake inhibitors or releasing agents for $3 \mathrm{H}$-biogenic amines in rat brain tissue slices. Eur J Pharmacol 45:329-333 
Heresco-Levy U, Javitt DC, Irmilov M, Mordel C, Horowitz A, Kelly D (1996): Double-blind, placebo-controlled, crossover trial of glycine adjuvant therapy for treatmentresistant schizophrenia. Br J Psychiatry 169:610-617

Kapur S, Remington G (1996): Serotonin-dopamine interaction and its relevance to schizophrenia. Am J Psychiatry 153:466-476

Kirkpatrick B, Buchanan RW, McKenney PD, Alphs LD, Carpenter WT (1989): The Schedule for the Deficit Syndrome: An instrument for research in schizophrenia. Psychiatry Res 30:119-130

Kirkpatrick B, Ram R, Amador XF, Buchanan RW, McGlashan T, Tohen M, Bromet E (1998): Summer birth and the deficit syndrome of schizophrenia. Am J Psychiatry 155:1221-1226

Kopelowicz A, Liberman RP, Mintz J, Zarate R (1997): Comparison of efficacy of social skills training for deficit and nondeficit negative symptoms in schizophrenia. Am J Psychiatry 154:424-425

Lieberman JA, Kane JM, Gadaleta D, Brenner R, Lesser MS, Kinon B (1984): Methylphenidate challenge as a predictor of relapse in schizophrenia. Am J Psychiatry 141:633-638

Lieberman JA, Kane JM, Sarantakos S, Galadeta D, Woerner M, Alvir J, Ramos-Lorenzi J (1987): Prediction of relapse in schizophrenia. Arch Gen Psychiatry 44:597-603

Lieberman JA, Safferman AZ, Pollack S, Szymanski S, Johns CA, Howard A, Kronig M, Bookstein P, Kane JM (1994): Clinical effects of clozapine in chronic schizophrenia: Response to treatment and predictors of outcome. Am J Psychiatry 151:1744-1752

Marder SR, Meibach RC (1994): Risperidone in the treatment of schizophrenia. Am J Psychiatry 151:825-835

Mathew RJ, Wilson WH (1989): Changes in cerebral blood flow and mental state after amphetamine challenge in schizophrenic patients. Neuropsychobiology 21:117-123

Meehl PE (1962): Schizotaxia, schizotypy, schizophrenia. Am Psychol 17:827-838

Nakachi N., Kiuchi Y, Inagaki M, Inazu, M, Yamazaki Y, Oguchi K (1995): Effects of various dopamine uptake inhibitors on striatal extracellular dopamine levels and behaviors in rats. Eur J Pharmacol 281:195-203

Ng JP, Menacherry SD, Liem BJ, Anderson D, Singer M, Justice JB (1992): Anomalous effect of mazindol on dopamine uptake as measured by in vivo voltammetry and microdialysis. Neurosci Lett 134:229-232

Overall JE, Gorham DR (1962): Brief Psychiatric Rating Scale. Psychol Rep 10:799-812

Paillère-Martinot M-L, Lecrubier Y, Martinot J-L, Aubin F (1995): Improvement of some schizophrenic deficit symptoms with low doses of amisulpride. Am J Psychiatry 152:130-133

Rado S (1956): Psychoanalysis of Behavior. New York, Grune \& Stratton.

Sanfilipo M, Wolkin A, Angrist B, van Kammen DP, Duncan E, Wieland S, Cooper TB, Peselow ED, Rotrosen J (1996): Amphetamine and negative symptoms of schizophrenia. Psychopharmacol 123:211-214

Schmidt CJ, Fadayel GM (1995): The selective 5-HT2A recep- tor antagonist, MDL 100,907, increases dopamine efflux in the prefrontal cortex of the rat. Eur J Pharmacol 273:273-279

Schultz W (1997): Dopamine neurons and their role in reward mechanisms. Curr Opin Neurobiol 7:191-197

Seibyl JP, Erdos J, Karper L, Johnson R, Brenner L, Heninger GR, Charney DS, Krystal JH (1992): Long-term mazindol augmentation in negative symptom schizophrenia. Soc Neurosci Abstr 18:95.4

Seibyl J, Krystal J, Johnson R, Brenner L, Heninger G, Charney D (1991): Mazindol augmentation of typical antipsychotics in negative symptom schizophrenics. Soc Neurosci Abstr 17:354

Silver H, Nassar A (1992): Fluvoxamine improves negative symptoms in treated chronic schizophrenia: An add-on double-blind, placebo-controlled study. Biol Psychiatry 31:698-704

Simpson GM, Angus JWS (1970): A rating scale for extrapyramidal side effects. Acta Psychiatr Scand 45(Suppl 212):11-19

Siris SG, Morgan V, Fagerstrom R, Rifkin A, Cooper TB (1987): Adjunctive imipramine in the treatment of postpsychotic depression: A controlled trial. Arch Gen Psychiatry 44:533-539

Small JG, Hirsch SR, Arvanitis LA, Miller BG, Link CGG, the Seroquel Study Group (1997): Quetiapine in patients with schizophrenia. Arch Gen Psychiatry 54:549-557

Spina E, De Domenico P, Ruello C, Longobardo N, Gitto C, Ancione M, Di Rosa AE, Caputi AP (1994): Adjunctive fluoxetine in the treatment of negative symptoms in chronic schizophrenic patients. Int Clin Psychopharmacol 9:281-285

Stein L, Wise CD (1971): 6-hydroxydopamine, noradrenergic reward, and schizophrenia. Science 171:1032

Strauss JS, Carpenter WT (1972): 6-hydroxydopamine, noradrenergic reward, and schizophrenia. Science 175: 921-922

Tamminga CA, Thaker GK, Buchanan R, Kirkpatrick B, Alphs LD, Chase TN, Carpenter WT (1992): Limbic system abnormalities identified in schizophrenia using positron emission tomography with fluorodeoxyglucose and neocortical alterations with deficit syndrome. Arch Gen Psychiatry 49:522-530

Tanda G, Carboni E, Frau R, Di Chiara G (1994): Increase of extracellular dopamine in the prefrontal cortex: A trait of drugs with antidepressant potential? Psychopharmacol 115:285-288

Tanda G, Pontieri FE, Frau R, Di Chiara G (1997): Contribution of blockade of the noradrenaline carrier to the increase of extracellular dopamine in the rat prefrontal cortex by amphetamine and cocaine. Eur J Neurosci 9:2077-2085

Thierry AM, Tassin JP, Blanc G, Glowinski J (1976): Selective activation of the mesocortical DA system by stress. Nature 263:242-244

Tollefson GD, Beasley CM, Tran PV, Street JS, Krueger JA, Tamura RN, Graffeo KA, Thieme ME (1997): Olanzapine versus haloperidol in the treatment of schizophrenia and schizoaffective disorders: Results of an 
international collaborative trial. Am J Psychiatry 154:457-465

Van Kammen DP, Boronow JJ (1988): Dextro-amphetamine diminishes negative symptoms in schizophrenia. Int Clin Psychopharmacol 3:111-121

Weinberger DR (1987): Implications of normal brain devel- opment for the pathogenesis of schizophrenia. Arch Gen Psychiatry 44:660-669

Yamagami S, Soejima K (1989): Effect of maprotiline combined with conventional neuroleptics against negative symptoms of chronic schizophrenia. Drugs Exptl Clin Res XV(4):171-176 